(c) American Dairy Science Association, 2006.

\title{
Effect of Barley and Its Amylopectin Content on Ruminal Fermentation and Nitrogen Utilization in Lactating Dairy Cows
}

\author{
A. E. Foley, ${ }^{\star}$ A. N. Hristov, ${ }^{\star 1}$ A. Melgar, ${ }^{\star}$ J. K. Ropp, ${ }^{*}$ R. P. Etter, ${ }^{\star}$ S. Zaman, ${ }^{\star}$ C. W. Hunt, ${ }^{\star}$ \\ K. Huber, $†$ and W. J. Priceł \\ *Department of Animal and Veterinary Science, \\ †Department of Food Science and Toxicology, and \\ ¥Statistical Programs, College of Agricultural and Life Sciences, University of Idaho, Moscow 83844
}

\section{ABSTRACT}

The effect of type of grain (corn vs. barley) and amylopectin content of barley grain (normal vs. waxy) on ruminal fermentation, digestibility, and utilization of ruminal ammonia nitrogen for milk protein synthesis was studied in a replicated $3 \times 3$ Latin square design trial with 6 lactating dairy cows. The experimental treatments were (proportion of dietary dry matter): CORN, $40 \%$ corn grain, NBAR, 30\% normal Baronesse barley: $10 \%$ corn grain, and WBAR, 30\% high-amylopectin (waxy) Baronesse barley:10\% corn grain. All grains were steam-rolled and fed as part of a total mixed ration. The NBAR and WBAR diets resulted in increased ruminal ammonia concentrations compared with CORN (8.2, 7.4, and $5.6 \mathrm{mM}$, respectively), but other ruminal fermentation parameters were not affected. Ruminal digestibility of dietary nutrients and microbial protein synthesis in the rumen were also not affected by diet. Corn grain had greater in situ effective ruminal dry matter degradability (62.8\%) than the barley grains (58.2 and $50.7 \%$, respectively), and degradability of the normal barley starch was greater than that of the waxy barley ( 69.3 and $58.9 \%$, respectively). A greater percentage of relative starch crystallinity was observed for the waxy compared with the normal barley grain. Total tract apparent digestibility of dry matter and organic matter were decreased by WBAR compared with CORN and NBAR. Total tract starch digestibility was greater and milk urea nitrogen content was lower for CORN compared with the 2 barley diets. In this study, the extent of processing of the grain component of the diet was most likely the factor that determined the diet responses. Minimal processing of barley grain (processing indexes of 79.2 to $87.9 \%$ ) reduced its total tract digestibility of starch compared with steam-rolled corn (processing index of 58.8\%). As a result of the increased ammonia concentration and reduced degradability of

Received March 15, 2006.

Accepted June 7, 2006.

${ }^{1}$ Corresponding author: ahristov@uidaho.edu barley dry matter in the rumen, the utilization of ruminal ammonia nitrogen for microbial protein synthesis was decreased with the barley diets compared with the corn-based diet. In this study, waxy Baronesse barley was less degradable in the rumen and the total digestive tract than its normal counterpart. The most likely reasons for these effects were the differences in starch characteristics and chemical composition, and perhaps the different response to processing between the 2 barleys.

Key words: corn grain, Baronesse barley, waxy barley, dairy cow

\section{INTRODUCTION}

Barley grain is often fed to lactating dairy cows in the western United States as an alternate energy source in place of corn grain. Barley is more fermentable in the rumen than corn (Herrera-Saldana et al., 1990; McAllister and Cheng, 1996), and diets based on barley grain produce greater ruminal dietary starch digestibility (Feng et al., 1995; Overton et al., 1995; Tothi et al., 2003) and in some cases increased ruminal concentration of VFA (Feng et al., 1995; Yang et al., 1997b; Khorasani et al., 2001) than corn-based diets. Processing is a major factor determining ruminal fermentability and the digestion rate of cereal grains (Plascencia and Zinn, 1996; Firkins et al., 2001), and animal responses to the type of grain may depend on the extent of grain processing. For example, the ruminal solubility of barley in feedlot cattle increased from 7.9 to $23.5 \%$ with an increased level of processing from coarse to flat (Beauchemin et al., 2001). Thus, the extent of processing may be used to regulate the rate of barley degradability in the rumen and minimize the risk of digestive disorders. As shown by Yang et al. (2000), the time ruminal $\mathrm{pH}$ was below 5.8 linearly increased with an increasing extent of barley grain processing in dairy cows.

There is significant variability in the characteristics of ruminal degradation among varieties of barley (Ramsey et al., 2001; Kaiser et al., 2004), and little is known 
about the effect of the barley starch composition on ruminal fermentation and digestion. In vitro results have suggested that the variety of barley and its amylopectin content could affect the microbial utilization of ammonia in the rumen (Hristov et al., 2002), but no in vivo data are available to confirm these observations. With corn grain, Akay and Jackson (2001) reported no effect of the amylopectin content of corn on the total tract apparent digestibility of dietary nutrients. Little research has been conducted with waxy barley varieties fed to ruminants.

The objective of this study was to investigate the effects of substituting steam-rolled corn grain with steam-rolled normal- or high-amylopectin (waxy) barley grain in the rations of lactating dairy cows on ruminal fermentation and efficiency of ammonia utilization, on the digestibility of nutrients, and on nitrogen losses. We hypothesized that 1) minimal processing of barley may reduce its rate of ruminal starch degradability, making it comparable to the degradability of corn grain; and 2) compared with normal barley, waxy barley may increase the efficiency of utilization of ruminal ammonia.

\section{MATERIALS AND METHODS}

\section{Animals and Feeding}

Six multiparous, late-lactation Holstein cows fitted with 10-cm ruminal cannulas (Bar Diamond, Parma, ID) were used in this experiment. Five of the cows were fitted with simple T-type duodenal cannulas (Ankom Technology, Fairport, NY). The duodenal cannulas were placed on the ascending duodenum, anterior to the pancreatic duct. The cows (BW $687 \pm 27 \mathrm{~kg}$; DIM $274 \pm 37 \mathrm{~d}$ at the beginning of the trial) were cared for according to the guidelines of the University of Idaho Animal Care and Use Committee and were subjected to the experimental treatments in a replicated Latin square design (incomplete for the duodenal measurements). Treatments were corn grain (CORN), normal barley grain (NBAR), and high-amylopectin (waxy) barley grain (WBAR). Waxy grain varieties contain very little amylose. Normal barley starch contains 20 to $30 \%$ amylose and 70 to $75 \%$ amylopectin, whereas waxy barley may contain less than $1 \%$ amylose (Bhatty, 1993). The 2 barley varieties (Baronesse) used in this experiment were grown by the same farmer side by side for the purpose of the trial and were provided to us by Western Plant Breeders, Inc. (Bozeman, MT). The normal and waxy barley phenotypes were confirmed by iodine staining of the grain endosperm $\left(0.2 \% \mathrm{wt} / \mathrm{vol} \mathrm{I}_{2}\right.$ and $2 \% \mathrm{wt} / \mathrm{vol} \mathrm{KI}$ ). In this procedure, the iodine forms a complex with starch molecules that varies in color with respect to the length of the starch chains; amylose
Table 1. Composition of the diets fed in the trial (\% of DM)

\begin{tabular}{|c|c|c|c|}
\hline \multirow[b]{2}{*}{ Item } & \multicolumn{3}{|c|}{ Treatment $^{1}$} \\
\hline & CORN & NBAR & WBAR \\
\hline \multicolumn{4}{|l|}{ Ingredient } \\
\hline Alfalfa hay, ${ }^{2}$ chopped & 19.0 & 19.0 & 19.0 \\
\hline Grass hav', chopped & 18.7 & 18.7 & 18.7 \\
\hline Cottonseed, whole with lint & 7.0 & 7.0 & 7.0 \\
\hline Corn grain, steam-rolled & 40.0 & 10.0 & 10.0 \\
\hline Barley grain ${ }^{3}$ steam-rolled & - & 30.0 & 30.0 \\
\hline Soybean meal, solvent $48 \% \mathrm{CP}$ & 9.9 & 9.9 & 9.9 \\
\hline Sugar beet pulp, dried & 3.0 & 3.0 & 3.0 \\
\hline Limestone & 0.9 & 0.9 & 0.9 \\
\hline Monosodium phosphate $\left(1 \mathrm{H}_{2} \mathrm{O}\right)$ & 0.1 & 0.1 & 0.1 \\
\hline Mineral premix ${ }^{4}$ & 1.0 & 1.0 & 1.0 \\
\hline Vitamin premix $^{5}$ & 0.4 & 0.4 & 0.4 \\
\hline \multicolumn{4}{|l|}{ Composition } \\
\hline $\mathrm{NE}_{\mathrm{L}}{ }^{6} \mathrm{Mcal} / \mathrm{kg}$ & 1.65 & 1.61 & 1.61 \\
\hline $\mathrm{CP}$ & 16.4 & 17.3 & 17.8 \\
\hline $\mathrm{NDF}$ & 35.9 & 38.5 & 39.1 \\
\hline Starch & 26.6 & 23.9 & 21.7 \\
\hline
\end{tabular}

${ }^{1} \mathrm{CORN}=$ Corn grain NBAR = normal $($ nonwaxy $)$ barley; WBAR = waxy (high-amylopectin) barley.

${ }^{2}$ Alfalfa hay was $90.3 \% \mathrm{DM}$ and (DM basis) $22.1 \% \mathrm{CP}$, and $35.4 \%$ $\mathrm{NDF}$; grass hay was $83.6 \% \mathrm{DM}$ and (DM basis) $8.8 \% \mathrm{CP}$, and $64.5 \%$ NDF.

${ }^{3}$ Normal (nonwaxy; NBAR) or waxy (high-amylopectin) barley (WBAR).

${ }^{4}$ Composition: 50 to $60 \% \mathrm{NaCl}, 3,500 \mathrm{mg} / \mathrm{kg}$ of $\mathrm{Mn}$ (as $\mathrm{MnSO}_{4}$ ), $3,000 \mathrm{mg} / \mathrm{kg}$ of $\mathrm{Zn}\left(\right.$ as $\mathrm{Zn} \mathrm{SO} \mathrm{SO}_{4}$ ), $750 \mathrm{mg} / \mathrm{kg}$ of $\mathrm{Cu}\left(\right.$ as Cu$_{2} \mathrm{SO}_{4}$ ), $20 \mathrm{mg} /$ $\mathrm{kg}$ of $\mathrm{Fe}\left(\right.$ as $\mathrm{Fe}_{2} \mathrm{CO}_{3}$ ), $85 \mathrm{mg} / \mathrm{kg}$ of I (as $\left.\mathrm{CaI}_{2} \mathrm{O}_{6} \cdot \mathrm{H}_{2} \mathrm{O}\right), 15 \mathrm{mg} / \mathrm{kg}$ of Co (as $\left.\mathrm{CoCO}_{3}\right), 35 \mathrm{mg} / \mathrm{kg}$ of $\mathrm{Se}\left(\right.$ as $\left.\mathrm{Na}_{2} \mathrm{SeO}_{2} \cdot 5 \mathrm{H}_{2} \mathrm{O}\right)$.

${ }^{5}$ Composition: $2,109 \mathrm{KIU} / \mathrm{kg}$ of vitamin A, $396 \mathrm{KIU} / \mathrm{kg}$ of vitamin $\mathrm{D}$, and $7.4 \mathrm{KIU} / \mathrm{kg}$ of vitamin $\mathrm{E}$.

${ }^{6}$ Estimated (NRC, 2001).

molecules (long chains) form a blue color based on the complex, and branched chains of amylopectin (relatively shorter chains) form a reddish-brown color. Thus, if the endosperm stains a purple-blue color, it is an amylose-containing starch. In CORN, steam-rolled corn grain was included at $40 \%$ (DM basis) in the diet and in NBAR and WBAR, 75\% of the corn grain was replaced by the respective steam-rolled barley variety (Table 1). This substitution rate was based on our previous in vitro results (Hristov et al., 2002). The volume weights of corn, normal barley, and waxy barley grains before processing were 74.7, 61.2 , and $60.6 \mathrm{~kg} / 100 \mathrm{~L}$, respectively. Concentrations (DM basis) of $\mathrm{CP}$, starch, and NDF in the 3 grains were 8.2,67.7, and $12.0 \% ; 11.2$, 52.5 , and $22.2 \%$; and $12.9,48.3$, and $22.7 \%$, respectively (Dairyland Laboratories, Inc., Arcadia, WI). Both corn and barley grains were steamed under similar conditions $\left(99^{\circ} \mathrm{C}\right.$ for 15 to $\left.20 \mathrm{~min}\right)$ and rolled. Roller settings were identical between the 2 barley grains. Kernel thickness was measured with a micrometer caliper on 30 kernels and was $1.88 \pm 0.022$ and $1.85 \pm 0.029 \mathrm{~mm}$ $(P=0.407)$ for the normal and waxy barleys, respectively. Volume weights of the processed grains were 43.9 , 48.5, and $53.3 \mathrm{~kg} / 100 \mathrm{~L}$, respectively. Thus, the 
processing indexes (PI, volume weight after processing as the percentage of volume weight before processing; Yang et al., 2000) for CORN, NBAR, and WBAR were $58.8,79.2$, and $87.9 \%$. Cows were fed at 0600 and 1800 at $95 \%$ of ad libitum intake determined at the beginning of the experiment. Diets were mixed in a Data Ranger (American Calan Inc., Northwood, NH). Each experimental period consisted of $14 \mathrm{~d}$ for adaptation to the diet and $7 \mathrm{~d}$ for sampling.

\section{Markers, Sampling, and Related Analyses}

Ruminal ammonia $\mathrm{N}$ was labeled through a $10 \mathrm{~g} / \mathrm{cow}$ pulse-dose of 20 atom percent excess (APE) $\left({ }^{15} \mathrm{NH}_{4}\right)_{2} \mathrm{SO}_{4}$ (Cambridge Isotope Laboratories, Inc., Andover, MA) dissolved in $7 \mathrm{~L}$ of McDougall's buffer (McDougall, 1948). On d 15, before the $0600 \mathrm{~h}$ feeding, the rumen of each cow was emptied into individual containers and weighed. Ruminal contents were thoroughly mixed. A background sample was collected and the isotope and $\mathrm{Cr}$ - and $\mathrm{Yb}$-based markers were added to the ruminal contents. Following mixing of the markers, a 0-h sample was collected and the ruminal contents were returned to the rumen of the cows. Chromium-EDTA (equivalent of $2.5 \mathrm{~g}$ of $\mathrm{Cr} / \mathrm{cow}$; Udén et al., 1980) was used as a ruminal liquid passage rate marker. Ytterbium-labeled alfalfa hay (Hristov and Broderick, 1996), dosed at $300 \mathrm{~g} / \mathrm{cow}$ (equivalent to 2.3 $\mathrm{g}$ of $\mathrm{Yb}$ ) was used to estimate solid passage rates.

Ruminal Sampling. Whole ruminal contents samples were collected at $0.5,1,2,4,6,8,10,14,18,24$, and $30 \mathrm{~h}$ following the dosing of markers at $0600 \mathrm{~h}$ on d 15 of each period. Two additional samples, at 34 and $38 \mathrm{~h}$, were collected for $\mathrm{Yb}$ analysis. Ruminal samples were collected from 4 locations in the rumen and the reticulum (approximately $250 \mathrm{~g}$ each), composited, and analyzed for DM, OM, ${ }^{15} \mathrm{~N}$ enrichment of the ammonia and NAN, and purine concentration in bacterial pellets (Hristov and Ropp, 2003). Purines were analyzed according to Zinn and Owens (1986) using the modified washing solution of Aharoni and Tagari (1991) and 0.6 $M \mathrm{HClO}_{4}$ (Makkar and Becker, 1999). Aliquots of the ruminal samples were filtered through 2 layers of cheesecloth, immediately analyzed for $\mathrm{pH}$, and processed for analyses of ammonia, total free AA, and reducing sugars as described by Hristov et al. (1999). Protozoal counts and polysaccharide-degrading (carboxymethylcellulase, amylase, and xylanase) and deaminative activities were also measured (Hristov et al., 2001). Aliquots of the cheesecloth-filtered ruminal fluid were acidified with $5 \%$ (wt/vol) meta- $\mathrm{H}_{3} \mathrm{PO}_{4}$ and analyzed for VFA. Volatile fatty acids were analyzed on an HP 5890 Series II gas-liquid chromatograph (HewlettPackard Co., Palo Alto, CA); the column was a $20 \mathrm{~m}$
WCOT fused-silica capillary, with EEAP-CB coating, $0.32 \mathrm{~mm}$ i.d. (Varian, Inc., Palo Alto, CA). Individual ruminal samples were analyzed for ammonia and $\mathrm{pH}$; the remaining analyses were performed on composite (all time points; volume or weight base) samples. Cheesecloth filtrates (after being centrifuged at 20,000 $\times g$ for 15 min at $4^{\circ} \mathrm{C}$ ) were analyzed for $\mathrm{Cr}$, and ruminal solids were analyzed for $\mathrm{Yb}$ (Soon, 1998) concentration (Iris ICP atomic emission spectrophotometer; Thermo Jarrell Ash Corp., Franklin, MA). Fractional outflow rates of the ruminal fluid and solid phases were calculated as ln-transformed $\mathrm{Cr}$ or $\mathrm{Yb}$ concentrations plotted vs. time.

Milk Sampling. Total milk output was measured and milk was analyzed for fat, true protein, and MUN during the last $7 \mathrm{~d}$ of each period (Washington DHIA, Burlington, WA). Milk urea N was analyzed enzymatically (modified Berthelot reaction) on a ChemSpec 150 analyzer (Bentley Instruments, Chaska, MN). Milk fat and protein were analyzed using a MilkoScan 6500 (Foss, Hillerød, Denmark). Following the ${ }^{15} \mathrm{~N}$ dose, cows were milked at 0 (background), 2.5, 5, 10, 15, 20, 25, $30,35,40,45,50,55,60,70,80,90,100,110,120,130$, and $140 \mathrm{~h}$. At each milking, milk weights were recorded and 2 milk samples were collected, one for analyses of milk fat, true protein, and MUN and another for analysis of ${ }^{15} \mathrm{~N}$ enrichment of the milk protein (Hristov and Ropp, 2003).

Calculations. Pool size of ruminal ammonia $\mathrm{N}$ was calculated as ruminal weight ( $\mathrm{kg}$, from ruminal evacuation on $\mathrm{d} 15) \times$ average ammonia $\mathrm{N}$ concentration ( $\mathrm{g} /$ $\mathrm{kg}$, from ruminal sampling). Ruminal ammonia and bacteria ${ }^{15} \mathrm{~N}$-enrichment (APE) curves were plotted vs. time (h) and fitted to a 3-parameter single-exponential decay model $\left[f=y_{0}+a \times \exp (-\underline{b} \times x)\right.$; Sigma Plot 8.0, SPSS Inc., Chicago, IL]. Milk ${ }^{15} \mathrm{~N}$-enrichment curves were fitted to a double-exponential model of the type $Y=a \times \exp (-c 1 \times x) \times \exp [-b \times \exp (-c 2 \times x)]$ (Dhanoa et al., 1985; PROC NLIN, SAS; SAS Institute, Inc., Cary, NC). Criteria for best fit were as described by Hristov and Ropp (2003), or the proportion of the variance explained by the model in the case of milk protein. The average adjusted $\mathrm{r}^{2}$ for the ruminal ammonia $\mathrm{N}$ and bacterial $\mathrm{N}$ models were $0.98 \pm 0.003$ and 0.94 \pm 0.011 , respectively. The average proportion of the variance explained by the milk protein model (regression sum of squares $\div$ uncorrected total sum of squares) was $0.86 \pm 0.014$. Areas under the predicted milk protein, ruminal ammonia, and bacterial ${ }^{15} \mathrm{~N}$ curves (AUC; ${ }^{15} \mathrm{~N}$ APE $\times \mathrm{h}$ ) were computed using the trapezoidal rule (AREA.XFM transform; SigmaPlot 8.0). Proportions of milk protein $\mathrm{N}$ originating from ruminal bacterial and ammonia $\mathrm{N}$ and the proportion of bacterial $\mathrm{N}$ originat- 
ing from ruminal ammonia $\mathrm{N}$ were derived based on the respective AUC (Nolan and Leng, 1974).

The total flux, irreversible loss, and recycling rate of ruminal ammonia $\mathrm{N}$ were calculated from ammonia ${ }^{15} \mathrm{~N}$-enrichment data, from the ${ }^{15} \mathrm{~N}$-ammonia AUC, and by the difference according to Nolan and Leng (1974). The microbial $\mathrm{N}$ leaving the rumen that originated from ruminal ammonia $\mathrm{N}$ was calculated as microbial $\mathrm{N}$ flow $\times$ proportion of bacterial $\mathrm{N}$ originating from ammonia $\mathrm{N}$. The proportion of the irreversible ammonia $\mathrm{N}$ loss incorporated into microbial protein leaving the rumen was calculated as [(microbial $\mathrm{N}$ flow $\times$ proportion of bacterial $\mathrm{N}$ derived from ammonia $\mathrm{N}) \div$ irreversible loss of ammonia N] $\times 100$.

The cumulative amount of ${ }^{15} \mathrm{~N}$ secreted into milk protein was calculated as milk output for each milking interval multiplied by the TCA-precipitable $\mathrm{N}$ concentration of milk (Hristov and Ropp, 2003) and by its ${ }^{15} \mathrm{~N}$ enrichment. Data were presented as the percentage of ${ }^{15} \mathrm{~N}$ dosed (for each individual cow) and were fitted to a single rectangular 2-parameter hyperbola model of the type: $f=a \times x \div(b+x)$ (PROC NLIN; SAS). In this case, $a$ represented the theoretical maximum of ${ }^{15} \mathrm{~N}$ secreted with milk protein as a percentage of ${ }^{15} \mathrm{~N}$ dosed in the rumen. Estimated maximum secretions and overall secretion lines were compared among diets using a dummy variable regression technique (Hristov and Ropp, 2003).

\section{Nutrient Flow at the Duodenum and Total Tract Digestibility Determinations}

Flow and ruminal digestibility of DM, OM, NAN, $\mathrm{NDF}$, and flow of microbial $\mathrm{N}$ at the duodenum were estimated using the double-marker method of Faichney (1975). Lithium:CoEDTA (Udén et al., 1980) and indigestible NDF (Rinne et al., 2002) were utilized as liquidand solid-phase markers, respectively. Total tract apparent digestibility of DM, OM, N, and NDF were determined using acid-insoluble ash (Van Keulen and Young, 1977) as an internal digestibility marker. Details on marker dosing, sampling, processing of samples, and analyses are given in Hristov and Ropp (2003).

\section{In Situ Degradability Trial}

Three of the cows in this trial were used to determine in situ degradability of the corn and barley grains. The diet fed to the cows consisted of (\%, DM basis) alfalfa hay, 41.2; steam-rolled corn, 23.4; dry-rolled barley, 8.4; shredded beet pulp, 6.9; whole cottonseed, 6.7; dried distillers grains, 7.3; and vitamin/mineral supplement, 6.1. Cows were fed ad libitum, twice daily. Grain samples for this trial were sieved through a $4.75-\mathrm{mm}$ sieve to remove fines. Flaked corn was incubated as it is in the rumen. Because the 2 barley grains were minimally processed (Figure 7), kernels were manually halved for the in situ incubation (McAllister et al., 1990). Bags (Ankom Technology, Fairport, NY), containing $5 \mathrm{~g}$ of air-dried grain sample were incubated in the rumen for 0 (water-washed, but not incubated in the rumen), 2 , $4,6,16,24$, and $36 \mathrm{~h}$. Bag processing following incubation and estimation of DM and starch degradability parameters were as described (Hristov et al., 2004b).

\section{Other Analyses}

Diets were sampled once weekly. Samples were composited per period, dried at $65^{\circ} \mathrm{C}$ to constant weight (approximately $72 \mathrm{~h}$ ) in a forced-air oven, and analyzed for ash (AOAC, 1999), acid-insoluble ash, N, and NDF (Ankom 200 Fiber Analyzer; Ankom Technology). A heat-stable amylase ( $\alpha$-amylase, EC 232.560.9; Sigma Chemical Co., St. Louis, MO) was used in the NDF analysis; sodium sulfite was not used in the analysis (Van Soest et al., 1991). Nitrogen and ${ }^{15} \mathrm{~N}$ enrichment of samples were analyzed on a Costech ECS 4010 C/N/ S elemental analyzer (Costech Analytical Technologies, Inc., Valencia, CA) interfaced to a Delta ${ }^{\text {plus }}$ isotope-ratio mass spectrometer (ThermoFinnigan MAT GmbH, Bremen, Germany). Samples were pulverized (Retsch MM200 micro mill; F. Kurt Retsch GmbH \& Co. KG, Haan, Germany) prior to the analysis. Starch concentration in feed, fecal, and duodenal samples was analyzed using a starch assay kit (Megazyme International Ireland Ltd., Wicklow, Ireland; McCleary et al., 1994).

Total urine was collected during the last $4 \mathrm{~d}$ of each period and analyzed for $\mathrm{N}$ and allantoin concentration. Urinary catheters (22 French, 75 cc; C. R. Bard Inc., Covington, GA) were positioned in the cows $24 \mathrm{~h}$ prior to initiating the urine collection. Urine was acidified ( $\mathrm{pH}<3.0$ ) with $2 \mathrm{M} \mathrm{H}_{2} \mathrm{SO}_{4}$ and diluted with distilled water for $\mathrm{N}$ (1:10) and allantoin (1:20) analyses (Hristov et al., 2000).

On the last $2 \mathrm{~d}$ of each period, blood samples were collected from the jugular vein before $(0 \mathrm{~h})$ and $6 \mathrm{~h}$ after the morning feeding. Plasma was collected after centrifugation at $1,500 \times g$ for $40 \mathrm{~min}$, frozen at $-40^{\circ} \mathrm{C}$, and later analyzed for urea N (PUN, Urea Nitrogen kit, catalog no. 640-8; Sigma Diagnostics, St. Louis, MO).

Powder x-ray diffraction patterns of the processed barley grains were obtained using a Siemens D5000 x-ray diffractometer (Bruker, Madison, WI). Samples were first finely ground in a cyclone mill and equilibrated to a moisture content of $15 \%$ prior to analysis. Xray diffraction data were collected using the parameters reported by Cheetham and Tao (1998) with the following modifications. Ground sample was packed tightly 
into rectangular aluminum cells and exposed to the $\mathrm{x}$ ray beam with the $\mathrm{x}$-ray generator running at $40 \mathrm{kV}$ and $30 \mathrm{~mA}$. The scanning regions of the diffraction angle $2 \Theta$ were 4 to $30^{\circ}$ with the following operational conditions: step intervals of 0.03 ; scan rate $2 \% \mathrm{~min}$; Sollet and divergence slit, $1^{\circ}$; receiving slit, $1^{\circ}$; and scattering slit, $0.15^{\circ}$. Starch crystallinity was calculated according to the procedure reported by Nara and Komiya (1983).

Gelatinization properties of the ground barley grains were analyzed by differential scanning calorimetry using a Pyris-1 thermal analytical system (PerkinElmer, Norwalk, CT). Starch samples [10.0 $\pm 0.1 \mathrm{mg}$ (dry basis)] were weighed directly into stainless-steel sample pans, mixed with deionized water $(20 \mu \mathrm{L})$ to form slurries, and sealed. Samples were allowed to equilibrate overnight, and were heated from 20 to $180^{\circ} \mathrm{C}$ at a rate of $10^{\circ} \mathrm{C} / \mathrm{min}$. A pan containing a $1: 2$ ratio of $\mathrm{Al}_{2} \mathrm{O}_{3}$ :water was used as a reference. Enthalpy change $(\Delta H)$ and gelatinization onset $\left(T_{\mathrm{o}}\right)$, peak $\left(T_{\mathrm{p}}\right)$, and completion $\left(T_{\mathrm{c}}\right)$ temperatures were computed from the endotherms (a measure of the amount of energy that is required to bring about melting of a crystalline material).

\section{Statistical Analysis}

All data were analyzed using SAS (2003; SAS Institute, Inc.). Intake, ruminal fermentation (except ammonia and $\mathrm{pH}$ ), duodenal nutrient flows, digestibility, urine, and isotope data were analyzed by ANOVA Latin square (PROC MIXED). The model used was

$$
\mathrm{y}_{\mathrm{ijkl}}=\mu+\mathrm{G}_{\mathrm{l}}+\mathrm{C}_{\mathrm{i}}\left(\mathrm{G}_{\mathrm{l}}\right)+\mathrm{P}_{\mathrm{j}}+\mathrm{T}_{\mathrm{k}}+\mathrm{e}_{\mathrm{ijkl}}
$$

where $\mu$ is the overall mean; G, C, P, and T are group (replicated Latin square), cow, period, and diet; and e is an error term under the usual assumptions for ANOVA (the error is distributed normally with mean $=0$ and a constant variance). Cow and group were included as random effects. For some variables (microbial $\mathrm{N}$ and microbial $\mathrm{N}$ from $\mathrm{NH}_{3}$ flows; ruminal starch degradability; and utilization of ruminal $\mathrm{NH}_{3} \mathrm{~N}$ for microbial protein synthesis) the model did not converge with both group and cow as random effects, and these variables were analyzed with cow alone as a random effect. All reported values are least squares means. Rumen $\mathrm{pH}$ and ammonia data were analyzed as Latin square repeated measures assuming an ar(1) covariance structure. Statistical analysis of total protozoal counts was performed on $\log _{10}$-transformed data. Data on starch characteristics were analyzed with one-way ANOVA. Statistical analysis of the in situ data was as described (Hristov et al., 2004b). Statistical difference was declared at $P \leq 0.10$. When the overall diet effect was $P$ $\leq 0.10$, diet means were separated by a pairwise $t$-test.

\section{RESULTS}

Overall, ruminal $\mathrm{pH}$ was not affected $(P=0.568)$ by type of diet (Table 2$) ; \mathrm{pH}$ declined $(P<0.001)$ steadily with time after feeding (Figure 1), and the time $\times$ diet interaction was not significant $(P=0.968)$. The average ruminal ammonia concentration was greater $(P<0.001)$ for the 2 barley diets compared with CORN. Ammonia concentrations followed a typical pattern, increasing after feeding and decreasing thereafter $(P<0.001$; Figure 2). There was a significant interaction between time after feeding and the main effect $(P=0.023)$. Ammonia concentrations were greater for NBAR compared with CORN at 2, 4, 6, 14, and $24 \mathrm{~h}$ after the morning feeding $(P=0.007$ to $<0.001)$. The WBAR diet resulted in a greater ammonia concentration compared with CORN at 2 and $4 \mathrm{~h}$ after feeding $(P=0.005$ and 0.004 , respectively). At $4 \mathrm{~h}$ after feeding, NBAR had a greater $(P=$ 0.011 ) ruminal ammonia concentration than WBAR.

The ruminal ammonia $\mathrm{N}$ pool, concentration of reducing sugars, total free AA in ruminal fluid, and protozoal counts were not affected ( $P=0.209$ to 0.842$)$ by diet (Table 2). Concentrations of total and individual VFA and polysaccharide-degrading and deaminative activities of ruminal fluid were also not different $(P=0.188$ to 0.949) among diets. Passage rates of fluids and solids, microbial $\mathrm{N}$ flow to the duodenum, flow of microbial $\mathrm{N}$ synthesized from ammonia, and the efficiency of microbial protein synthesis were not affected $(P=0.271$ to 0.976 ) by diet. Similarly, the daily urinary allantoin excretion was not different $(P=0.671)$ among diets.

Intake of DM, OM, N, and NDF were not different $(P=0.135$ to 0.766$)$ among diets (Table 3 ). Starch intake was greater $(P=0.007)$ for CORN compared with WBAR and tended to be greater $(P=0.121)$ compared with NBAR. Ruminal true digestibility of nutrients was not affected ( $P=0.186$ to 0.985$)$ by diet. Total tract apparent digestibility of $\mathrm{DM}$ and $\mathrm{OM}$ was greater $(P=0.003$ and 0.005 , respectively) for CORN and NBAR compared with WBAR. Digestibility of NDF was greater $(P=$ $0.033)$ for NBAR compared with WBAR and digestibility of N was greater $(P=0.082)$ for NBAR compared with CORN and WBAR. Total tract apparent digestibility of dietary starch was greater $(P=0.008)$ for CORN compared with the barley diets.

Average milk yields were $21.2,20.9$, and $19.6 \mathrm{~kg} / \mathrm{d}$ ( $\mathrm{SE}=1.39$; CORN, NBAR, and WBAR, respectively) and were not affected $(P=0.225)$ by diet. Milk fat and protein percentages $(3.80,3.79$, and $3.89 \%$ and 3.25 , 3.20 , and $3.16 \%$, respectively; $P=0.796$ and 0.541$)$ and yields also did not differ $(P=0.828$ and 0.203 , respectively) among diets. Secretion of $\mathrm{N}$ with milk was similar $(P=0.203)$ among diets, but as a proportion of $\mathrm{N}$ intake was greater $(P=0.036)$ for CORN compared with 
Table 2. Effect of grain type and barley amylopectin content on ruminal fermentation in dairy cows $(\mathrm{n}=$ $18 ; \mathrm{n}=270$ for $\mathrm{pH}$ and ammonia concentration)

\begin{tabular}{|c|c|c|c|c|c|}
\hline \multirow[b]{2}{*}{ Item } & \multicolumn{3}{|c|}{$\operatorname{Diet}^{1}$} & \multirow[b]{2}{*}{ SEM } & \multirow[b]{2}{*}{$P^{2}$} \\
\hline & CORN & NBAR & WBAR & & \\
\hline $\mathrm{pH}$ & 6.19 & 6.19 & 6.15 & 0.100 & 0.567 \\
\hline $\mathrm{NH}_{3}, \mathrm{~m} M$ & $5.6^{\mathrm{b}}$ & $8.2^{\mathrm{a}}$ & $7.4^{\mathrm{a}}$ & 0.38 & $<0.001$ \\
\hline $\mathrm{NH}_{3}-\mathrm{N},{ }^{3} \mathrm{~g}$ & 6.6 & 7.0 & 7.6 & 0.83 & 0.771 \\
\hline Total free AA, mM & 4.6 & 5.0 & 4.6 & 0.99 & 0.842 \\
\hline Reducing sugars, $\mathrm{m} M$ & 6.7 & 7.6 & 8.2 & 0.79 & 0.209 \\
\hline Total protozoa, ${ }^{4} \times 10^{4}$ cells $/ \mathrm{mL}$ & $\begin{array}{l}12.6 \\
(5.01)\end{array}$ & $\begin{array}{l}13.6 \\
(5.12)\end{array}$ & $\begin{array}{l}14.4 \\
(5.15)\end{array}$ & $(0.092)$ & $(0.652)$ \\
\hline VFA, $\mathrm{m} M$ & 129.2 & 133.7 & 133.1 & 4.17 & 0.611 \\
\hline Acetate & 78.9 & 84.8 & 84.4 & 2.33 & 0.188 \\
\hline Propionate & 29.5 & 26.3 & 26.7 & 2.11 & 0.420 \\
\hline iso-Butyrate & 1.07 & 1.17 & 1.08 & 0.061 & 0.571 \\
\hline Butyrate & 15.8 & 17.7 & 17.1 & 0.93 & 0.518 \\
\hline iso-Valerate & 1.86 & 1.82 & 1.82 & 0.228 & 0.949 \\
\hline Valerate & 2.04 & 1.91 & 2.03 & 0.141 & 0.599 \\
\hline Acetate:propionate & 2.83 & 3.24 & 3.24 & 0.175 & 0.203 \\
\hline \multicolumn{6}{|l|}{ PSD activities ${ }^{5}$} \\
\hline CMCase & 39.6 & 51.1 & 47.4 & 6.24 & 0.546 \\
\hline Xylanase & 144.3 & 170.0 & 155.2 & 10.15 & 0.383 \\
\hline Amylase & 46.3 & 38.9 & 40.3 & 2.84 & 0.302 \\
\hline Deaminative activity $^{6}$ & 2.8 & 3.2 & 3.4 & 0.40 & 0.609 \\
\hline Liquid-phase FOR, ${ }^{7} \% / \mathrm{h}$ & 12.0 & 12.5 & 12.4 & 0.62 & 0.920 \\
\hline Solid-phase FOR, $\% / \mathrm{h}$ & 4.1 & 4.0 & 4.1 & 0.40 & 0.976 \\
\hline Microbial N (MN) flow, g/d & 258 & 244 & 260 & 22.9 & 0.854 \\
\hline $\mathrm{MN}$ from $\mathrm{NH}_{3}$ flow ${ }^{8} \mathrm{~g} / \mathrm{d}$ & 162 & 138 & 145 & 18.6 & 0.630 \\
\hline MN, g/kg OMTDR ${ }^{9}$ & 26 & 22 & 25 & 2.2 & 0.271 \\
\hline Urinary allantoin, $\mathrm{g} / \mathrm{d}$ & 56.3 & 49.9 & 53.1 & 4.08 & 0.671 \\
\hline
\end{tabular}

\footnotetext{
${ }^{\mathrm{a}, \mathrm{b}}$ Within a row, means without a common superscript letter $\operatorname{differ}(P<0.10)$.

${ }^{1} \mathrm{CORN}=$ Corn; NBAR = normal (nonwaxy) barley; WBAR = waxy (high-amylopectin) barley.

${ }^{2}$ Overall diet effect.

${ }^{3} \mathrm{Ammonia} \mathrm{N}$ pool size (g) estimated from rumen evacuation data and ammonia concentration in ruminal fluid.

${ }^{4}$ Values shown are means of actual counts. The values in parentheses are the means of $\log _{10}$ transformations of the data immediately above.

${ }^{5} \mathrm{PSD}=$ Polysaccharide-degrading activities. Expressed as nanomoles of reducing sugars as glucose released per milliliter of ruminal fluid per minute; CMCase = carboxymethylcellulase.

${ }^{6}$ Expressed as micromoles of ammonia released from $1 \mathrm{~mL}$ of ruminal fluid per hour.

${ }^{7} \mathrm{FOR}=$ Fractional outflow rate.

${ }^{8}$ Calculated as: $\mathrm{MN}$ flow $\times$ proportion of bacterial $\mathrm{N}$ originating from ammonia $\mathrm{N}$ (area under the curve data).

${ }^{9}$ OMTDR $=$ Organic matter truly digested in the rumen.
}

NBAR and WBAR (Table 4). Similarly, urinary, fecal, and total $\mathrm{N}$ losses were not affected $(P=0.170$ to 0.323$)$ by diet. As a proportion of $\mathrm{N}$ intake, more $(P=0.080)$ $\mathrm{N}$ was lost with the urine with WBAR than with CORN and NBAR, and more $(P=0.082) \mathrm{N}$ was lost with feces with CORN and WBAR than with NBAR. As a proportion of $\mathrm{N}$ intake, total (urine and feces) $\mathrm{N}$ losses were similar $(P=0.451)$ among diets. Plasma urea $\mathrm{N}$ concentrations did not differ $(P=0.864)$ among diets, but the 2 barley diets resulted in greater $(P=0.001)$ MUN concentrations compared with CORN.

Overall ${ }^{15} \mathrm{~N}$ enrichment of ruminal ammonia $\mathrm{N}$ was not affected $(P=0.926)$ by diet, but ${ }^{15} \mathrm{~N}$ enrichment of bacterial and milk protein $\mathrm{N}$ were greater $(P=0.094$ and 0.042 , respectively) for CORN compared with
NBAR (bacterial N) and with NBAR and WBAR (milk protein N; Table 5 and Figures 3 through 5 ). The areas under the ammonia ${ }^{15} \mathrm{~N}$-enrichment curves (AUC) were not different $(P=0.677)$ among diets, but bacterial and milk protein AUC were greater $(P=0.081$ and 0.099 , respectively) for CORN compared with NBAR and WBAR. The proportions of bacterial $\mathrm{N}$ originating from ammonia $\mathrm{N}$ and milk protein $\mathrm{N}$ originating from bacterial and ammonia $\mathrm{N}$ were not different $(P=0.204$ to 0.735 ) among diets. Irreversible ammonia $\mathrm{N}$ loss from the rumen, ruminal ammonia $\mathrm{N}$ flux, and recycling were also not affected $(P=0.242$ to 0.920$)$ by diet. The rate of utilization of ruminal ammonia $\mathrm{N}$ for microbial protein synthesis was greater $(P=0.064)$ for CORN compared with NBAR and WBAR. The estimated cumu- 


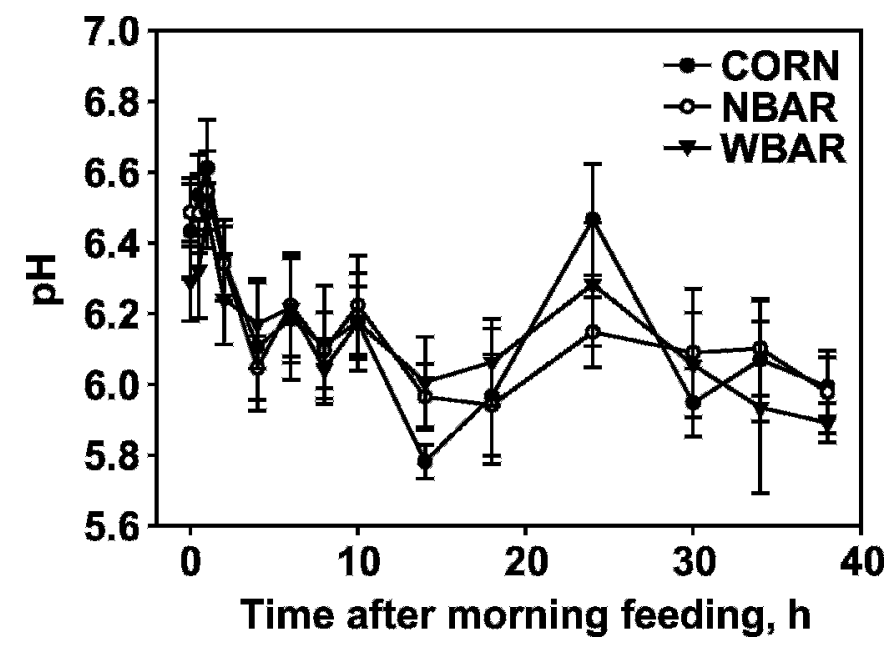

Figure 1. Effect of grain type on ruminal $\mathrm{pH}$ in dairy cows (means $\pm \mathrm{SE}) . \mathrm{CORN}=$ corn; NBAR = normal (nonwaxy) barley; WBAR = waxy (high-amylopectin) barley. Overall diet effect, $P=0.582$; diet $\times$ time of sampling interaction, $P=0.968$.

lative maximum ammonia ${ }^{15} \mathrm{~N}$ secreted in milk protein was not affected $(P=0.479$ to 0.986$)$ by diet. Cumulative milk protein ${ }^{15} \mathrm{~N}$ secretion curves (Figure 6) did not differ between CORN and NBAR $(P=0.713)$ or NBAR and WBAR $(P=0.451)$. Over the course of the experiment, cumulatively more $(P=0.078)$ ruminal ammonia ${ }^{15} \mathrm{~N}$ was secreted in milk protein with CORN than with WBAR.

The corn grain used to formulate the CORN diet had greater $(P<0.001)$ ruminal solubility of $\mathrm{DM}$ and starch compared with the normal and waxy barleys (Table 6).

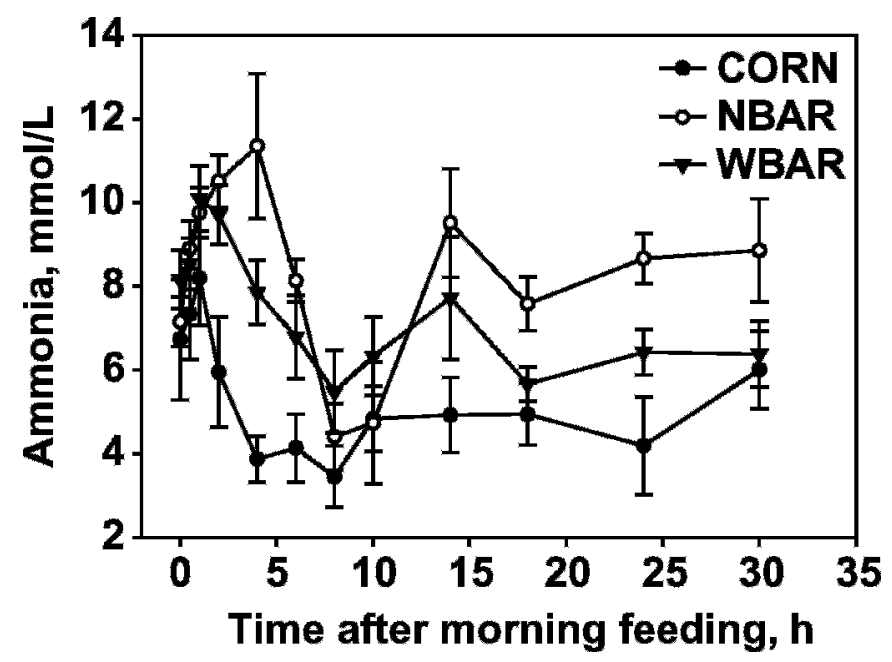

Figure 2. Effect of grain type on ruminal ammonia concentration in dairy cows (means $\pm \mathrm{SE})$. CORN = corn; NBAR = normal (nonwaxy) barley; WBAR = waxy (high-amylopectin) barley. Overall diet effect, $P=0.006$; diet $\times$ time of sampling interaction, $P=0.027$.
Solubility of starch from the normal barley was greater $(P=0.054)$ compared with the waxy barley. The normal barley had a greater $(P=0.012$ to 0.104 and $P=0.014$ to $0.053, \mathrm{DM}$ and starch, respectively) rate of degradation of the potentially degradable DM and starch than did the corn and waxy barley grains. The estimated effective degradability of DM in the rumen was greater for CORN than for NBAR $(P=0.004)$ and WBAR $(P<$ $0.001)$. The effective degradability of starch did not differ $(P=0.627)$ between CORN and NBAR, but was lower $(P<0.001)$ for WBAR compared with the other 2 grains.

Analysis of the processed normal and waxy barley grains revealed inherent differences in their starch characteristics (Table 7). Although no difference was observed for the 2 grains with regard to starch gelatinization enthalpy $(P=0.289)$, the waxy barley possessed higher starch gelatinization onset $(P=0.004)$, peak $(P$ $<0.001)$ and completion $(P<0.001)$ temperatures than did the normal barley. A greater percentage of relative starch crystallinity was also observed for the waxy relative to the normal barley $(P=0.040)$.

\section{DISCUSSION}

Because substitution of corn with barley was on a weight basis, the NBAR and WBAR diets contained greater proportions of NDF and less starch than did the CORN diet. Respectively, intake of NDF was numerically greater and that of starch was lower (or numerically lower) with the 2 barley diets as compared with the CORN diet. Compared with corn grain, barley has a higher $\mathrm{CP}$ content and the 2 barley diets contained greater concentrations of $\mathrm{N}$, which resulted in numerically greater $\mathrm{N}$ intake compared with the CORN diet. This, in combination with the greater ruminal degradability rate of barley protein (Herrera-Saldana et al., 1990), explains the increased ruminal ammonia concentration with NBAR and WBAR, compared with CORN. Similar increases in ruminal ammonia concentration following substitution of corn with barley were reported by Tothi et al. (2003), although no effect was observed by Khorasani et al. (2001), and Overton et al. (1995) reported a linear decrease in ruminal ammonia as a result of an increasing proportion of barley grain in the diet. However, carbohydrate fermentation was not affected by grain type in the present trial, as was evident from ruminal $\mathrm{pH}$ and the VFA concentrations. Compared with the starch in corn, the starch in barley grain is highly fermentable in the rumen (Overton et al., 1995; Firkins et al., 2001; Offner et al., 2003), but reports on the effect of grain type on ruminal $\mathrm{pH}$ and VFA concentrations are not consistent. In some studies, 
Table 3. Effect of grain type and barley amylopectin content on nutrient intakes and digestibility in dairy cows $(\mathrm{n}=18)$

\begin{tabular}{|c|c|c|c|c|c|}
\hline \multirow[b]{2}{*}{ Item } & \multicolumn{3}{|c|}{$\operatorname{Diet}^{1}$} & \multirow[b]{2}{*}{ SEM } & \multirow[b]{2}{*}{$P^{2}$} \\
\hline & $\mathrm{CORN}$ & NBAR & WBAR & & \\
\hline \multicolumn{6}{|c|}{ Intake, $\mathrm{kg} / \mathrm{d}$} \\
\hline $\mathrm{DM}$ & 20.4 & 21.0 & 20.4 & 0.55 & 0.766 \\
\hline $\mathrm{OM}$ & 18.8 & 19.3 & 18.5 & 0.51 & 0.669 \\
\hline $\mathrm{N}$ & 0.535 & 0.580 & 0.581 & 0.0314 & 0.184 \\
\hline $\mathrm{NDF}$ & 7.3 & 8.1 & 8.0 & 0.21 & 0.135 \\
\hline Starch $^{3}$ & $5.4^{\mathrm{a}}$ & $5.0^{\mathrm{a}}$ & $4.4^{\mathrm{b}}$ & 0.14 & 0.007 \\
\hline \multicolumn{6}{|c|}{ Ruminal true digestibility, $\%$} \\
\hline DM & 51.2 & 57.0 & 53.5 & 2.38 & 0.418 \\
\hline $\mathrm{OM}$ & 53.7 & 58.6 & 54.1 & 2.55 & 0.487 \\
\hline NDF & 45.7 & 46.0 & 46.7 & 3.80 & 0.985 \\
\hline $\mathrm{N}$ & 55.6 & 68.1 & 61.5 & 5.11 & 0.186 \\
\hline $\operatorname{Starch}^{4}$ & 80.4 & 81.6 & 75.4 & 2.77 & 0.318 \\
\hline \multicolumn{6}{|c|}{ Total tract apparent digestibility, $\%$} \\
\hline DM & $65.5^{\mathrm{a}}$ & $64.6^{\mathrm{a}}$ & $61.0^{\mathrm{b}}$ & 0.54 & 0.003 \\
\hline $\mathrm{OM}$ & $67.9^{\mathrm{a}}$ & $67.1^{\mathrm{a}}$ & $62.9^{\mathrm{b}}$ & 0.67 & 0.005 \\
\hline $\mathrm{NDF}$ & $53.2^{\mathrm{ab}}$ & $55.6^{\mathrm{a}}$ & $50.2^{\mathrm{b}}$ & 1.02 & 0.033 \\
\hline $\mathrm{N}$ & $61.7^{\mathrm{b}}$ & $64.0^{\mathrm{a}}$ & $62.2^{\mathrm{b}}$ & 0.58 & 0.082 \\
\hline Starch & $97.2^{\mathrm{a}}$ & $93.2^{\mathrm{b}}$ & $92.9^{b}$ & 0.69 & 0.008 \\
\hline
\end{tabular}

${ }^{\mathrm{a}, \mathrm{b}}$ Within a row, means without a common superscript letter $\operatorname{differ}(P<0.10)$.

${ }^{1} \mathrm{CORN}=$ Corn; NBAR = normal (nonwaxy) barley; WBAR = waxy (high-amylopectin) barley.

${ }^{2}$ Overall diet effect.

${ }^{3}$ CORN vs. NBAR, $P=0.121$.

${ }^{4}$ Not corrected for microbial starch flow.

substituting corn with barley grain did not affect the pH and VFA concentration (Feng et al., 1995; Casper et al., 1999; Tothi et al., 2003), but others reported decreased $\mathrm{pH}$ (Overton et al., 1995) or increased VFA concentration with barley- compared with corn-based diets (Yang et al., 1997b; Martin-Orue et al., 2000; Khorasani et al., 2001). The rate of ruminal in vitro degradation of isolated barley starch does not seem to differ from that of isolated cornstarch (Cone and Wolters, 1990), and it is processing (Svihus et al., 2005) and the protein matrix surrounding the starch granules (McAllister and Cheng, 1996) that determine the rate of starch degradability in the rumen. In the present study, a greater extent of kernel processing (flat vs. coarse for the 2 barley varieties) and intake of starch with CORN are most likely the reasons for the lack of a difference between CORN and NBAR and WBAR in ruminal $\mathrm{pH}$ and the VFA concentrations. As demonstrated by Offner et al. (2003) and discussed by Svihus et al. (2005), processing might have a greater impact on

Table 4. Effect of grain type and barley amylopectin content on nitrogen secretion in milk, urinary and fecal nitrogen losses, and plasma (PUN) and milk (MUN) urea $\mathrm{N}$ concentrations in dairy cows $(\mathrm{n}=18)$

\begin{tabular}{lccccc}
\hline & \multicolumn{5}{c}{ Diet $^{1}$} \\
\cline { 2 - 4 } Item & CORN & NBAR & WBAR & SEM & $P^{2}$ \\
\hline${\text { Milk N yield, }{ }^{3} \text { g/d }}_{\text {As \% of N intake }}^{107}$ & $19.2^{\mathrm{a}}$ & 102 & 96 & 4.1 & 0.203 \\
Urinary N, g/d & 163 & $17.3^{\mathrm{b}}$ & $16.5^{\mathrm{b}}$ & 0.84 & 0.036 \\
As \% of N intake & $31.6^{\mathrm{b}}$ & 186 & 193 & 18.1 & 0.170 \\
Fecal N, g/d & 204 & $31.6^{\mathrm{b}}$ & $36.9^{\mathrm{a}}$ & 3.28 & 0.080 \\
As \% of N intake & $38.3^{\mathrm{a}}$ & 308 & 219 & 5.78 & 0.323 \\
Total N loss, g/d & 367 & $36.0^{\mathrm{b}}$ & $37.8^{\mathrm{a}}$ & 0.57 & 0.082 \\
As \% of N intake & 68.7 & 68.4 & 412 & 19.9 & 0.204 \\
PUN, mg/100 mL & 16.8 & 16.2 & 71.5 & 3.10 & 0.451 \\
MUN, mg/100 mL & $10.4^{\mathrm{b}}$ & $13.8^{\mathrm{a}}$ & 16.7 & 0.87 & 0.864 \\
\hline
\end{tabular}

${ }^{a, b}$ Within a row, means without a common superscript letter differ $(P<0.10)$.

${ }^{1} \mathrm{CORN}=$ Corn; NBAR = normal (nonwaxy) barley; WBAR = waxy (high-amylopectin) barley .

${ }^{2}$ Overall diet effect.

${ }^{3}$ Milk $\mathrm{N}$ yield $=$ milk true protein yield $\div 6.38$. 
Table 5. Effect of grain type and barley amylopectin content on ${ }^{15} \mathrm{~N}$ enrichment of various $\mathrm{N}$ pools and ${ }^{15} \mathrm{~N}$ calculations in dairy cows $(\mathrm{n}=$ 18)

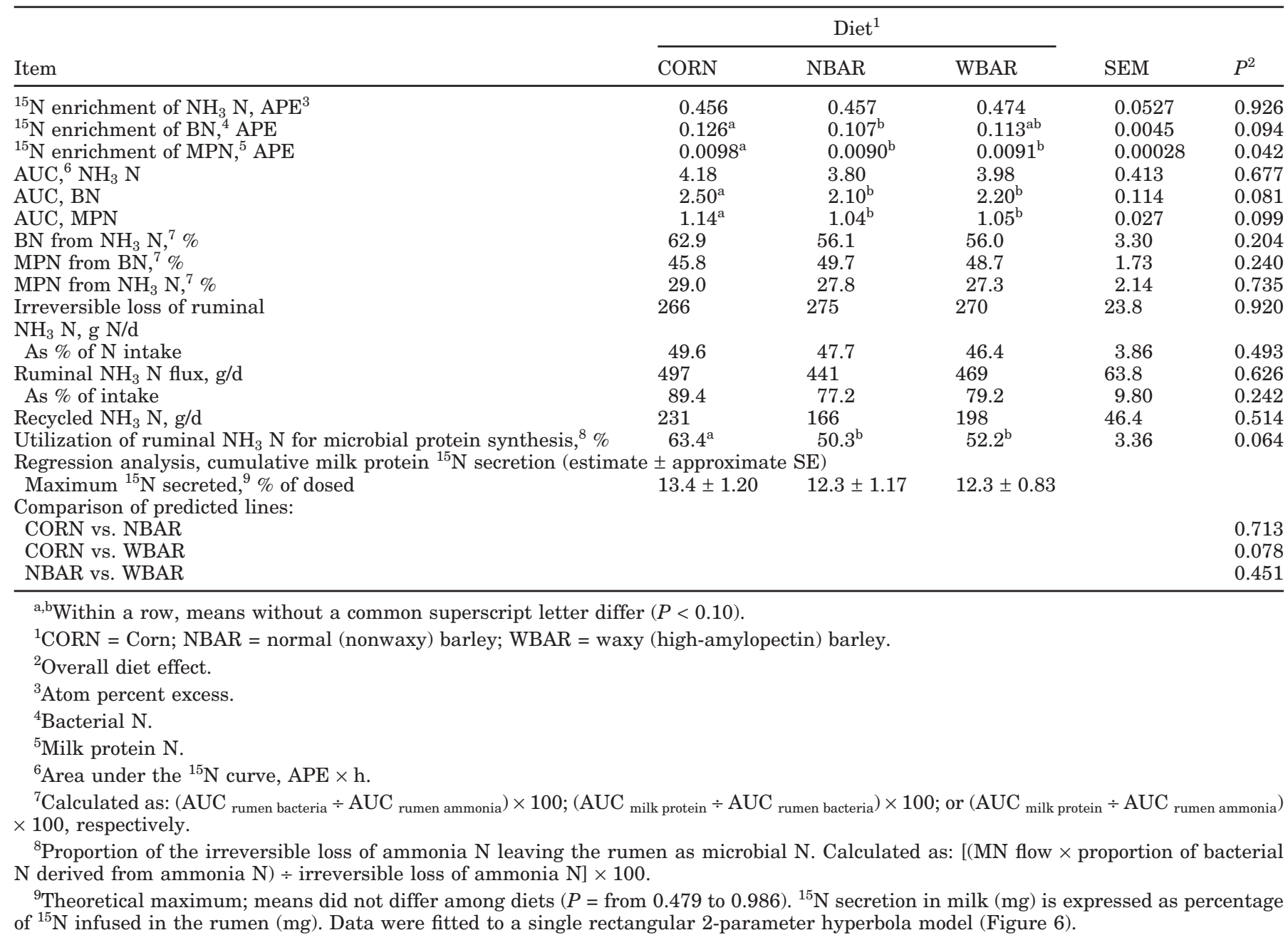

ruminal digestion of starch from grains with stronger starch-protein bonds, such as corn, than on the digestion of grains with weaker bonds, such as barley or wheat.

In theory, greater ruminal degradability of barley vs. cornstarch should result in elevated microbial protein synthesis and flow to the small intestine and, with a few exceptions (Overton et al., 1995; Casper et al., 1999), this concept is supported by the literature (Zinn, 1993; Feng et al., 1995; Yang et al., 1997b; Martin-Orue et al., 2000). In the present study, however, we did not observe increased microbial protein outflow from the rumen with the barley-based diets compared with the corn-based diet. Again, we believe this was mostly due to the level of processing of the grain component of the diets. The in situ data indicated greater starch solubility of corn vs. normal or waxy barley grains. The rate of degradation of the insoluble (and potentially degradable) starch fraction, however, was greater for normal barley than for corn grain. This latter observation is in accordance with other reports (Feng et al., 1995, Russell variety only; Yang et al., 1997a; Tothi et al., 2003). Apparently, when sufficient access to microbial digestion is provided (as in the study by Tothi et al., 2003, in which both grains were ground), starch in barley grain is more rapidly degradable in the rumen than starch in corn. However, as demonstrated in the present study, the extent of kernel processing is critical and may determine the rate and overall ruminal degradability of cereal grain DM and starch.

In this study, we found no significant differences in ruminal fermentation and microbial protein synthesis and flow between diets based on normal or waxy barley grain. Our previous in vitro data suggested that waxy barley varieties might have a stimulatory effect on ammonia utilization in the rumen (Hristov et al., 2002), but this effect was not confirmed in vivo because microbial $\mathrm{N}$ synthesized from ammonia in the rumen was 


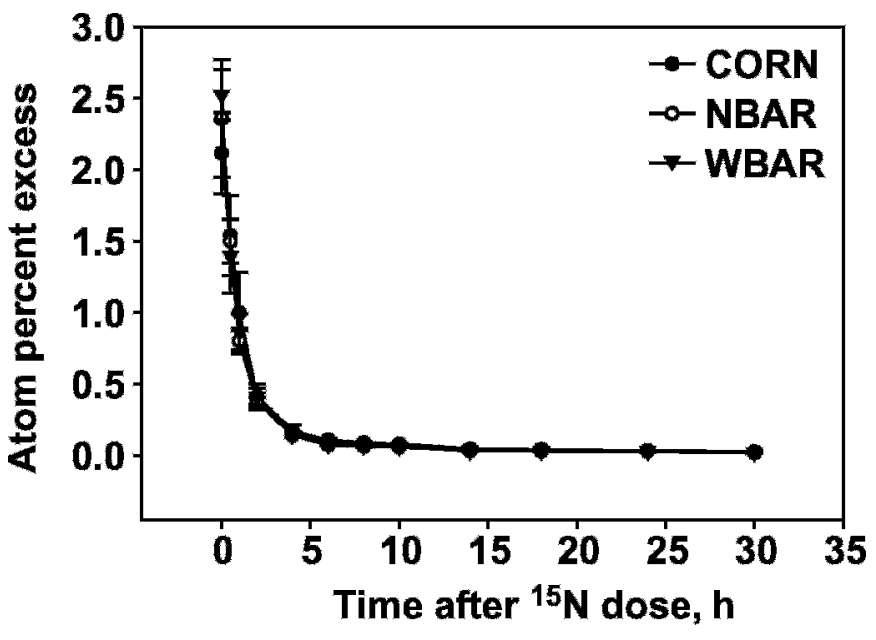

Figure 3. Effect of grain type on ${ }^{15} \mathrm{~N}$ enrichment of ruminal ammonia $\mathrm{N}$ in dairy cows (means $\pm \mathrm{SE}$ ). $\mathrm{CORN}=$ corn; $\mathrm{NBAR}=$ normal (nonwaxy) barley; WBAR = waxy (high-amylopectin) barley. Overall diet effect, $P=0.926$.

not different between NBAR and WBAR. The ruminally soluble starch fraction, rate of starch degradation, and in situ effective degradability of waxy barley starch (and DM) were lower than that of normal barley. Although there was a difference in the processing index of the 2 grains ( 79.2 and $87.9 \%$, normal and waxy barley, respectively), kernels were manually halved before in situ incubation, which should have provided equal access for microbial digestion. The extent of processing clearly affects microbial access (McAllister et al., 1990) and rate of digestion of barley (Yang et al., 2000) and cereal grains in general. High-amylopectin cereals, in-

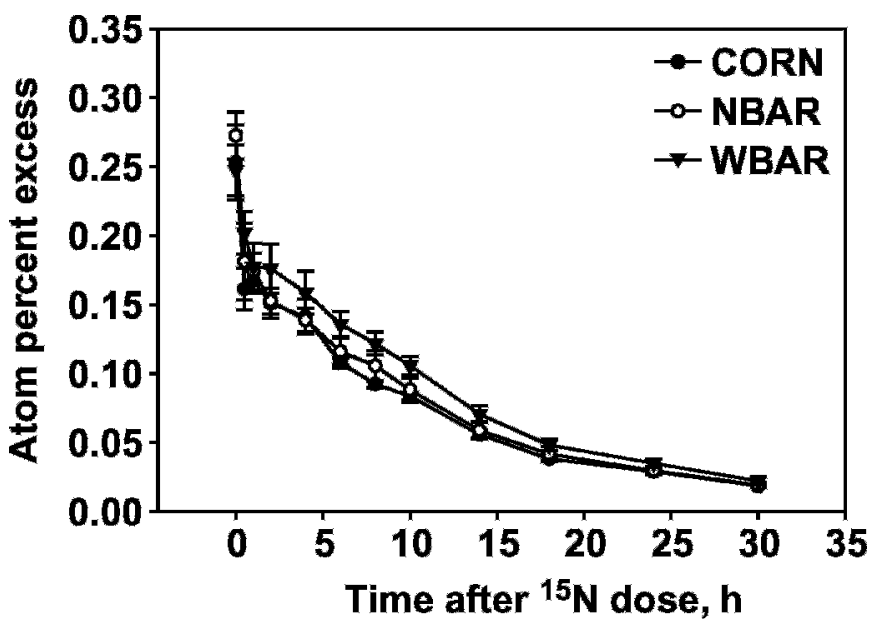

Figure 4. Effect of grain type on ${ }^{15} \mathrm{~N}$ enrichment of ruminal bacterial $\mathrm{N}$ in dairy cows (means $\pm \mathrm{SE}$ ). $\mathrm{CORN}=$ corn; $\mathrm{NBAR}=$ normal (nonwaxy) barley; WBAR = waxy (high-amylopectin) barley. Overall diet effect, $P=0.094$.

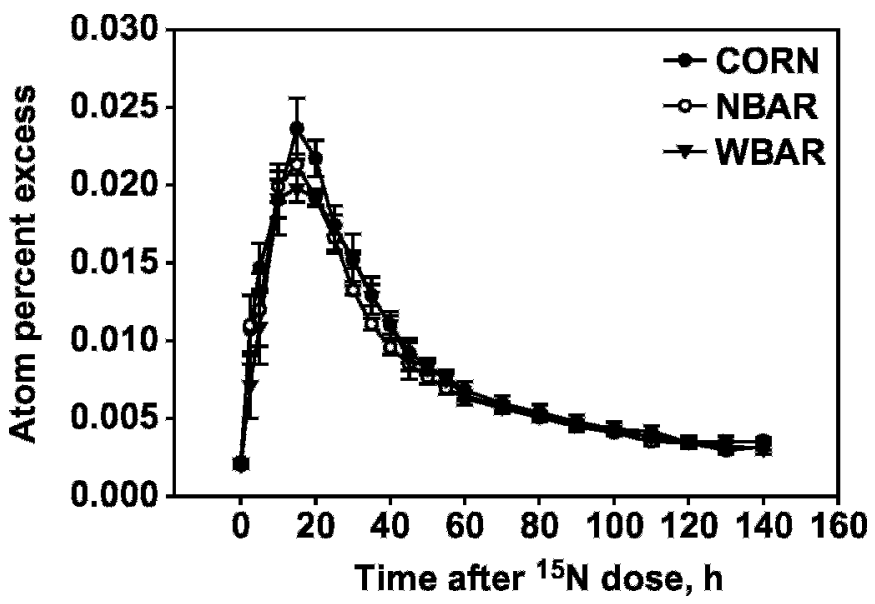

Figure 5. Effect of grain type on ${ }^{15} \mathrm{~N}$ enrichment of milk protein $\mathrm{N}$ in dairy cows (means \pm SE). CORN = corn; NBAR = normal (nonwaxy) barley; WBAR = waxy (high-amylopectin) barley. Overall diet effect, $P=0.042$

cluding barley, contain little amylose and are considered to be more susceptible to degradation by $\alpha$-amylases than their nonwaxy counterparts (Kotarski et al., 1992; MacGregor and Fincher, 1993; Svihus et al., 2005). However, some reports have indicated a faster rate of hydrolysis of normal vs. high-amylopectin barley starch in vitro (Tang et al., 2002). Vasanthan and Bhatty (1996) reported a 2-stage hydrolysis rate (rapid initial stage followed by a slower second stage) for normal and waxy barley starches subjected to $\alpha$-amylase digestion. Although waxy barley starch exhibited a

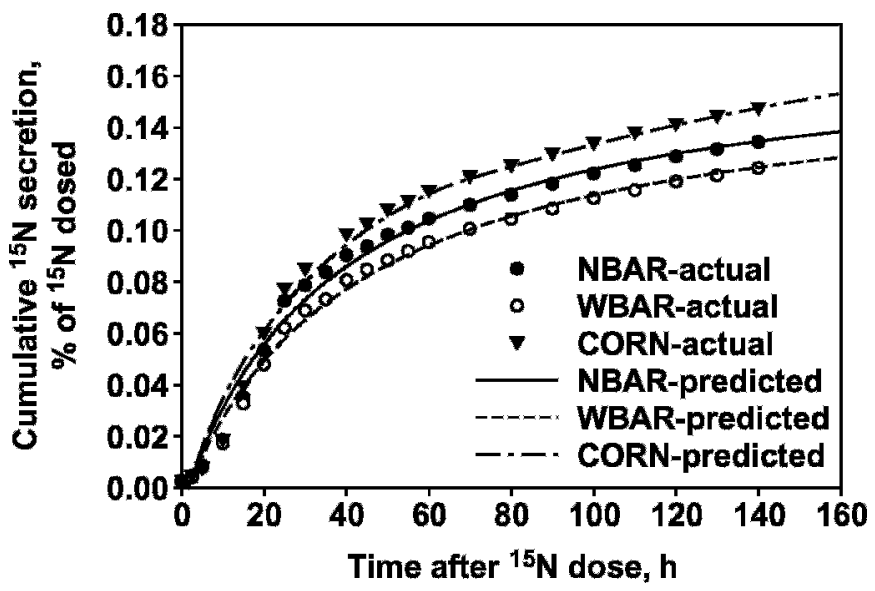

Figure 6. Effect of grain type on cumulative secretion of ${ }^{15} \mathrm{~N}$ in milk protein (as the percentage of ${ }^{15} \mathrm{~N}$ dosed intraruminally). Symbols are measured values and lines are predicted values (single rectangular 2-parameter hyperbola model). $\mathrm{CORN}=$ corn; $\mathrm{NBAR}=$ normal (nonwaxy) barley; WBAR = waxy (high-amylopectin) barley . Comparison of predicted lines: CORN vs. NBAR, $P=0.713$; CORN vs. WBAR, $P=0.078 ;$ NBAR vs. WBAR, $P=0.451$. 
Table 6. Parameters of in situ ruminal degradability of DM and starch from steam-rolled corn and barley grains used in the experiment $(\mathrm{n}=63)$

\begin{tabular}{|c|c|c|c|}
\hline \multirow[b]{2}{*}{ Item } & \multicolumn{3}{|c|}{ Grain } \\
\hline & Corn & Normal barley & Waxy barley \\
\hline \multicolumn{4}{|l|}{$\mathrm{DM}^{1}$} \\
\hline Soluble and instantly degradable, $\%$ & $26.4 \pm 2.40^{\mathrm{a}}$ & $5.3 \pm 2.49^{\mathrm{b}}$ & $4.5 \pm 2.30^{\mathrm{b}}$ \\
\hline Potentially degradable $(b), \%$ & $59.9 \pm 3.32^{\mathrm{b}}$ & $77.0 \pm 2.88^{\mathrm{a}}$ & $80.3 \pm 3.75^{\mathrm{a}}$ \\
\hline Rate of degradation of $b, \% / \mathrm{h}$ & $9.3 \pm 1.79^{\mathrm{b}}$ & $13.1 \pm 1.51^{\mathrm{a}}$ & $8.1 \pm 1.22^{\mathrm{b}}$ \\
\hline Effective degradability, \% & $62.8 \pm 1.10^{\mathrm{a}}$ & $58.2 \pm 1.10^{\mathrm{b}}$ & $50.7 \pm 1.09^{\mathrm{c}}$ \\
\hline \multicolumn{4}{|l|}{ Starch $^{2}$} \\
\hline Soluble and instantly degradable, \% & $31.2 \pm 2.86^{\mathrm{a}}$ & $14.4 \pm 2.62^{\mathrm{b}}$ & $7.3 \pm 2.47^{\mathrm{c}}$ \\
\hline Potentially degradable $(b), \%$ & $67.1 \pm 4.51^{\mathrm{c}}$ & $82.8 \pm 3.18^{\mathrm{b}}$ & $93.7 \pm 4.64^{\mathrm{a}}$ \\
\hline Rate of degradation of $b, \% / \mathrm{h}$ & $7.5 \pm 1.71^{b}$ & $11.9 \pm 1.40^{\mathrm{a}}$ & $7.3 \pm 1.13^{b}$ \\
\hline Effective degradability, \% & $68.5 \pm 1.19^{\mathrm{a}}$ & $69.3 \pm 1.20^{\mathrm{a}}$ & $58.9 \pm 1.18^{\mathrm{b}}$ \\
\hline
\end{tabular}

${ }^{\mathrm{a}-\mathrm{c}}$ Within a row, means without a common superscript letter $\operatorname{differ}(P<0.10)$.

${ }^{1}$ Dry matter degradation lines differed at corn vs. normal barley, $P<0.001$; corn vs. waxy barley, $P<$ 0.001 ; and normal barley vs. waxy barley, $P<0.001$.

${ }^{2}$ Starch degradation lines differed at corn vs. normal barley, $P<0.001$; corn vs. waxy barley, $P<0.001$; and normal barley vs. waxy barley, $P<0.001$.

higher rate of initial hydrolysis, the reverse trend was true for the reduced (second) stage of hydrolysis. This observation is likely explained by a greater percentage of starch relative crystallinity (crystalline regions are not generally susceptible to enzyme hydrolysis) for waxy compared with normal native starch granules (Tang et al., 2002). In comparing several starch characteristics of the processed barley grains of the present study, we found that the percentage of relative crystallinity of the waxy barley starch was greater than that of the normal barley (Table 7) and consequently may have been more resistant to enzyme hydrolysis. The gelatinization properties of the starches within the processed barley grains also revealed a higher gelatinization onset, peak, and completion temperature for the waxy relative to the normal barley grain (Table 7), suggesting a more highly ordered structure for the waxy barley phenotype (relative to normal barley) starch crystallites. Both of these observations would be consis-

Table 7. Effect of barley type and amylopectin content on starch gelatinization behavior and relative crystallinity within processed grain samples

\begin{tabular}{|c|c|c|c|}
\hline \multirow[b]{2}{*}{ Analysis } & \multicolumn{2}{|c|}{ Grain } & \multirow[b]{2}{*}{$P^{1}$} \\
\hline & $\begin{array}{l}\text { Normal } \\
\text { barley }\end{array}$ & $\begin{array}{l}\text { Waxy } \\
\text { barley }\end{array}$ & \\
\hline \multicolumn{4}{|c|}{ Differential scanning calorimetry ${ }^{2}$} \\
\hline Onset temperature, ${ }^{\circ} \mathrm{C}$ & 62.9 & 65.4 & 0.004 \\
\hline Peak temperature, ${ }^{\circ} \mathrm{C}$ & 69.1 & 73.0 & $<0.001$ \\
\hline Completion temperature, ${ }^{\circ} \mathrm{C}$ & 76.1 & 81.1 & $<0.001$ \\
\hline Enthalpy, $\Delta H$ & 3.4 & 3.8 & 0.289 \\
\hline \multicolumn{4}{|l|}{ Powder x-ray diffraction ${ }^{2}$} \\
\hline Crystallinity, \% & 16.7 & 21.6 & 0.040 \\
\hline
\end{tabular}

${ }^{1}$ Overall diet effect.

${ }^{2}$ Values represent means of at least duplicate measurements. tent with a decreased soluble starch level and a reduced DM and starch effective degradability for the waxy compared with the normal barley grain.

Research on the effect of type of starch on digestion in nonruminants is conflicting. Although a recent comprehensive review by Svihus et al. (2005) concluded that waxy cereal grains are expected to have greater starch digestion than normal varieties, the mechanisms involved are not clearly understood. With broilers, Bergh et al. (1999) reported that birds fed diets based on normal barley weighed more, consumed more feed, and had a lower feed conversion ratio compared with birds consuming waxy barley-based diets. The difference was generally attributed to the greater content of $\beta$-glucans in waxy compared with normal barley. The fact that waxy barleys have a greater content of dietary fiber and $\beta$-glucans than normal barley varieties has been well established (Andersson, 1999). However, other reports found no differences in the DM digestibility or energy content of barley for pigs or poultry attributable to starch type (Miller et al., 1994). In a mobile bag study with pigs, waxy Steptoe barley had significantly greater $\mathrm{ADF}$ and $\beta$-glucans contents than normal Steptoe and the hull, pericarp, embryo, and aleurone layer fractions of the latter variety had greater DM digestibility and digestible energy contents than the corresponding waxy Steptoe fractions. With corn, for which soluble fiber is not a concern, diets based on waxy corn produced greater average daily gain and carcass weight in pigs than diets based on normal corn (Camp et al., 2003).

Research with waxy cereals in ruminants is scarce. A report by Schroeder et al. (1998) found no differences in milk yield of dairy cows fed diets containing various amounts of waxy corn. Fermentation in the rumen was also not affected. A study by Akay et al. (2002) indicated 


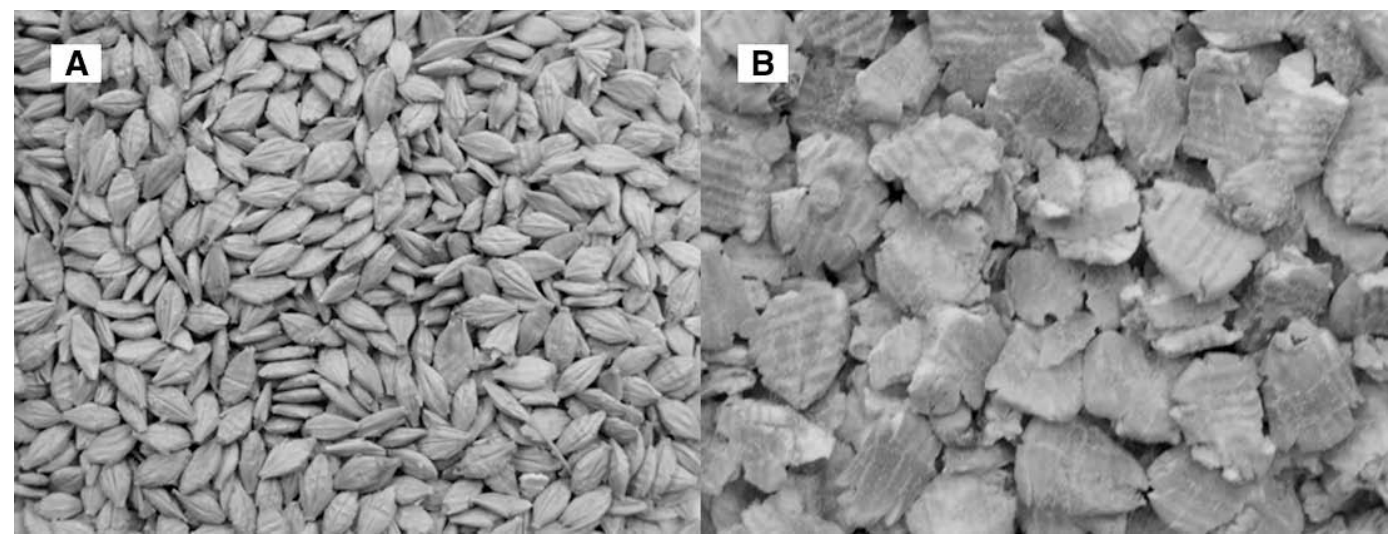

Figure 7. Processed normal barley (panel A) and corn (panel B) grains used in the trial.

a dramatic increase in ruminal starch digestion with waxy vs. normal corn, but this did not correspond to improvement in microbial protein synthesis or intestinal flow. In situ data by Philippeau et al. (1998) found no effect of the amylose:amylopectin ratio on ruminal degradation of cornstarch. No difference in ruminal degradability of waxy vs. normal sorghum starch was reported by Hibberd et al. (1982). With barley, however, ruminal degradability may be dictated not only by the type of starch, but also by the differences in fiber content between the normal and waxy varieties. As shown by Miller et al. (1994), Andersson (1999), and Bergh et al. (1999), waxy barleys contain more fiber and $\beta$-glucans than their normal counterparts. Bergh et al. (1999) also reported a greater ash content for waxy barley. There was no difference in NDF content of the 2 barleys used in the present study, but the starch content was lower with the waxy compared with the normal barley ( 48.3 vs. $52.5 \%$ ). Thus, the decreased in situ rate of degradation and effective degradability of waxy barley DM compared with the normal Baronesse barley might have been influenced by a greater content of soluble fiber and by other (nonstarch) components with the waxy variety. Interactions with endosperm cell walls or protein may affect starch degradability by ruminal microorganisms (Kotarski et al., 1992), which may account for the reduced rate and extent of waxy vs. normal barley starch degradability observed in the present study. Microbial digestion of starch is dependent on the digestibility of the protein matrix surrounding the starch granules (McAllister and Cheng, 1996; Yu, 2004). To our knowledge, no reports with barley are available, but research with corn (Philippeau et al., 1998) and sorghum (Rooney and Pflugfelder, 1986) indicated similar concentrations of true glutelins (constituting the protein matrix) in waxy and normal corn, or greater ruminal degradability of the protein matrix in waxy than in normal sorghum. In the study by Philippeau et al. (1998), protein fractions had no effect on ruminal degradability of cornstarch in situ. Last, there was a difference in the PI between waxy and normal barley (79.2 vs. $87.9 \%$, respectively), which also could have contributed to the differences in digestibility between the 2 grains. Because roller settings, and consequently kernel thickness, were identical for both barleys, the difference in PI may indicate different responses to processing between waxy and normal barley. However, it is unlikely that processing was a factor in the in situ experiment, because kernels of both barley types were halved and microorganisms would have had equal access to the endosperm tissues.

The barley-based diets had decreased total tract starch digestibility compared with the corn grain-based diet, which is in contrast to the greater barley starch digestibility reported by others (Reynolds et al., 1993; Feng et al., 1995; Yang et al., 1997a,b). As discussed, this effect was most likely due to the greater extent of corn-grain processing compared with the extent of processing of the 2 barleys (flat vs. coarse). The NBAR diet had greater apparent total tract $\mathrm{N}$ digestibility than CORN (or WBAR), which is consistent with some reports (Zinn, 1993; Martin-Orue et al., 2000; Khorasani et al., 2001) but not with others (Yang et al., 1997a,b; Khalili et al., 2001). Based on the in situ DM and starch degradability and the chemical composition data, we believe the considerably lower total tract nutrient digestibility of WBAR compared with NBAR was mainly due to differences in chemical composition (soluble fiber and starch crystallinity) between the 2 grains. Overall, our data indicate that when coarsely rolled (PI of around 80\%), barley may have lower ruminal and total tract digestibility than flatly rolled corn (PI of around $60 \%$ ). Although no statistical differences were observed, the in vivo ruminal digestibility of WBAR 
starch was numerically lower than that of NBAR starch.

The absolute amounts of $\mathrm{N}$ lost in feces or urine were not affected by diet. However, because the barley diets resulted in greater $\mathrm{N}$ intake, proportionally less dietary $\mathrm{N}$ was used for milk protein synthesis than with the corn-based diet. The greater total tract digestibility of NBAR N resulted in proportionally less $\mathrm{N}$ excreted with feces compared with the other 2 diets. Both barley diets produced greater MUN concentrations, although PUN levels were not affected. Similarly, Casper et al. (1999) found no effect of barley vs. corn on PUN, but Khalili et al. (2001) reported reduced PUN when corn was substituted for barley in diets for dairy cows. The increased MUN levels in the present study correspond well to the greater concentration of ruminal ammonia with the barley-based diets and indicate less efficient utilization of NBAR and WBAR $\mathrm{N}$ in the rumen compared with the corn-based diet. This conclusion is supported by the lowered ${ }^{15} \mathrm{~N}$-derived efficiency of utilization of ruminal ammonia $\mathrm{N}$ for microbial protein synthesis with the barley diets. Apart from this effect, however, ruminal ammonia $\mathrm{N}$ irreversible loss and flux were not affected by the diet. Because the size of the ruminal ammonia $\mathrm{N}$ pool and the average ${ }^{15} \mathrm{~N}$ enrichment of ruminal ammonia $\mathrm{N}$ were similar among diets (Table 2), the lowered ${ }^{15} \mathrm{~N}$ enrichment of bacterial and milk protein $\mathrm{N}$ with the barley diets appears to reflect reduced uptake of ammonia N compared with the CORN diet. The proportions of milk protein $\mathrm{N}$ originating from bacterial $\mathrm{N}$ and ruminal ammonia $\mathrm{N}$ are within the range observed in our previous experiments in which this isotope technique was used (Hristov et al., 2004a; Hristov et al., 2005). As demonstrated previously, the amount of ruminal $\mathrm{N}$ transferred into milk protein is determined by the efficiency of utilization of ruminal ammonia for microbial protein synthesis in the rumen (Hristov et al., 2005). In the present experiment, however, the increased efficiency of utilization of ruminal ammonia with the CORN diet resulted in statistically more efficient overall transfer of ${ }^{15} \mathrm{~N}$ ammonia into milk protein compared with the WBAR diet only. The theoretical maximum of ${ }^{15} \mathrm{~N}$ secreted in milk was within the range observed in other experiments (Hristov et al., 2004a; Hristov et al., 2005)

\section{CONCLUSIONS}

Substituting $75 \%$ of the corn with barley grain in the diets of lactating dairy cows resulted in increased ruminal ammonia concentrations, but other fermentation parameters were not affected. In this study, the extent of processing of the grain component of the diet appeared to be the factor that determined the overall fermentation characteristics and ruminal and total tract digestibility of dietary nutrients. Coarsely rolled barley grain had reduced total tract digestibility of starch compared with flatly rolled corn. As a result of the increased ammonia concentration and reduced degradability of barley DM, the utilization of ruminal ammonia $\mathrm{N}$ for microbial protein synthesis was decreased compared with the CORN diet. In this study, WBAR was less fermentable in the rumen than its normal counterpart, which resulted in decreased total tract digestibility of dietary nutrients of the diet based on the former grain. The most likely reasons for these effects were the differences in starch characteristics, differences in chemical composition, and perhaps different responses to processing between the 2 barleys.

\section{ACKNOWLEDGMENTS}

This study was partially supported by funds from the Idaho Barley Commission and the Idaho Agricultural Experiment Station. The authors would like to thank the staff of the Department of Animal and Veterinary Science Experimental Dairy for their conscientious care of the experimental cows.

\section{REFERENCES}

Aharoni, Y., and H. Tagari. 1991. Use of nitrogen-15 determinations of purine nitrogen fraction of digesta to define nitrogen metabolism traits in the rumen. J. Dairy Sci. 74:2540-2547.

Akay, V., and J. A. Jackson, Jr. 2001. Effects of NutriDense and waxy corn hybrids on the rumen fermentation, digestibility, and lactational performance of dairy cows. J. Dairy Sci. 84:1698-1706.

Akay, V., J. A. Jackson, and D. L. Harmon. 2002. NutriDense and waxy corn hybrids: Effects on site and extent of disappearance of nutrients in sheep. J. Anim. Sci. 80:1335-1343.

Andersson, A. 1999. Characterisation of barley and barley fractions, with emphasis on dietary fibre and starch. Acta Univ. SueciaeAgraria 194 (51 pages).

AOAC. 1999. Official Methods of Analysis. 17th ed. 5th rev. Assoc. Offic. Anal. Chem., Arlington, VA.

Beauchemin, K. A., W. Z. Yang, and L. M. Rode. 2001. Effects of barley grain processing on the site and extent of digestion of beef feedlot finishing diets. J. Anim. Sci. 79:1925-1936.

Bergh, M. O., A. Razdan, and P. Åman. 1999. Nutritional influence of broiler chicken diets based on covered normal, waxy and high amylose barleys with or without enzyme supplementation. Anim. Feed Sci. Technol. 78:215-226.

Bhatty, R. S. 1993. Nonmalting uses of barley. Pages $355-417$ in Barley Chemistry and Technology. A. W. MacGregor and R. S. Bhatty, ed. American Association of Cereal Chemists Inc., St. Paul, MN.

Camp, L. K., L. L. Southern, and T. D. Bidner. 2003. Effect of carbohydrate source on growth performance, carcass traits, and meat quality of growing-finishing pigs. J. Anim. Sci. 81:2488-2495.

Casper, D. P., H. A. Maiga, M. J. Brouk, and D. J. Schingoethe. 1999. Synchronization of carbohydrate and protein sources on fermentation and passage rates in dairy cows. J. Dairy Sci. 82:1779-1790.

Cheetham, N. W. H., and L. Tao. 1998. Variation in the crystalline type with amylose content in maize starch granules. Carbohydr. Polym. 36:277-284.

Cone, J. W., and M. G. E. Wolters. 1990. Some properties and degradability of isolated starch granules. Starch Starke 42:298-301. 
Dhanoa, M. S., R. C. Siddons, J. France, and D. L. Gale. 1985. A multicompartmental model to describe marker excretion patterns in ruminant feces. Br. J. Nutr. 53:663-671.

Faichney, G. J. 1975. The use of markers to partition digestion within the gastrointestinal tract of ruminants. Pages 277-291 in Digestion and Metabolism in the Ruminant. Proc. IV Int. Symp. Ruminant Physiol. I. W. McDonald and A. C. I. Warner, ed. The University of New England Publishing Unit, Sydney, Australia.

Feng, P., C. W. Hunt, G. T. Pritchard, and S. M. Parish. 1995. Effect of barley variety and dietary barley content on digestive function in beef steers fed grass hay-based diets. J. Anim. Sci. 73:34763484 .

Firkins, J. L., M. L. Eastridge, N. R. St-Pierre, and S. M. Noftsger. 2001. Effects of grain variability and processing on starch utilization by lactating dairy cattle. J. Anim. Sci. 79(E. Suppl.):E218E238.

Herrera-Saldana, R. E., J. T. Huber, and M. H. Poore. 1990. Dry matter, crude protein, and starch degradability of five cereal grains. J. Dairy Sci. 73:2386-2393.

Hibberd, C. A., D. G. Wagner, R. L. Schemm, D. E. Mitchell, Jr., D. E. Weibel, and R. L. Hintz. 1982. Digestibility characteristics of isolated starch from sorghum and corn grain. J. Anim. Sci. 55:1490-1497.

Hristov, A. N., and G. Broderick. 1996. Synthesis of microbial protein in ruminally cannulated cows fed alfalfa silage, alfalfa hay, or corn silage. J. Dairy Sci. 79:1627-1637.

Hristov, A. N., R. P. Etter, J. K. Ropp, and K. L. Grandeen. 2004a. Effect of dietary crude protein level and degradability on ruminal fermentation and nitrogen utilization in lactating dairy cows. J. Anim. Sci. 82:3219-3229.

Hristov, A. N., K. L. Grandeen, J. K. Ropp, and D. Greer. 2004b. Effect of grain type and Yucca schidigera-based surfactant on ammonia utilization in vitro and in situ degradability of corn grain. Anim. Feed Sci. Technol. 115:341-355.

Hristov, A. N., M. Ivan, L. M. Rode, and T. A. McAllister. 2001. Fermentation characteristics and ruminal ciliate protozoal populations in cattle fed medium- or high-concentrate barley-based diets. J. Anim. Sci. 79:515-524.

Hristov, A. N., T. A. McAllister, and K.-J. Cheng. 2000. Intraruminal supplementation with increasing levels of exogenous polysaccharide-degrading enzymes: Effects on nutrient digestion in cattle fed a barley grain diet. J. Anim. Sci. 78:477-487.

Hristov, A. N., T. A. McAllister, F. H. Van Herk, K.-J. Cheng, C. J. Newbold, and P. R. Cheeke. 1999. Effect of Yucca schidigera on ruminal fermentation and nutrient digestion in heifers. J. Anim. Sci. 77:2554-2563.

Hristov, A. N., and J. K. Ropp. 2003. Effect of dietary carbohydrate composition and availability on utilization of ruminal ammonia nitrogen for milk protein synthesis in dairy cows. J. Dairy Sci. 86:2416-2427.

Hristov, A. N., J. K. Ropp, K. L. Grandeen, S. Abedi, R. P. Etter, A. Melgar, and A. E. Foley. 2005. Effect of carbohydrate source on ammonia utilization in lactating dairy cows. J. Anim. Sci. 83:408-421.

Hristov, A. N., J. K. Ropp, and C. W. Hunt. 2002. Effect of barley and its amylopectin content on ruminal fermentation and bacterial utilization of ammonia-N in vitro. Anim. Feed Sci. Technol. 99:25-36.

Kaiser, C. R., J. G. P. Bowman, L. M. M. Surber, T. K. Blake, and J. J. Borkowski. 2004. Variation in apparent component digestibility of barley in the rat from the core collection of the USDA National Small Grains Collection. Anim. Feed Sci. Technol. 113:97-112.

Khalili, H., A. Sairanen, K. Hissa, and P. Huhtanen. 2001. Effects of type and treatment of grain and protein source on dairy cow performance. Anim. Sci. 72:573-584.

Khorasani, G. R., E. K. Okine, and J. J. Kennelly. 2001. Effects of substituting barley grain with corn on ruminal fermentation characteristics, milk yield, and milk composition of Holstein cows. J. Dairy Sci. 84:2760-2769.

Kotarski, S. F., R. D. Waniska, and K. K. Thurn. 1992. Starch hydrolysis by the ruminal microflora. J. Nutr. 122:178-190.
MacGregor, A. W., and G. B. Fincher. 1993. Carbohydrates of the barley grain. Pages 73-130 in Barley Chemistry and Technology. A. W. MacGregor and R. S. Bhatty, ed. American Association of Cereal Chemists Inc., St. Paul, MN.

Makkar, H. P. S., and K. Becker. 1999. Purine quantification in digesta from ruminants by spectrophotometric and HPLC methods. Br. J. Nutr. 81:107-112.

Martin-Orue, S. M., J. Balcells, F. Vicente, and C. Castrillo. 2000. Influence of dietary rumen-degradable protein supply on rumen characteristics and carbohydrate fermentation in beef cattle offered high-grain diets. Anim. Feed Sci. Technol. 88:59-77.

McAllister, T. A., and K.-J. Cheng. 1996. Microbial strategies in the ruminal digestion of cereal grains. Anim. Feed Sci. Technol. 62:29-36.

McAllister, T. A., L. M. Rode, D. J. Major, K.-J. Cheng, and J. G. Buchanan-Smith. 1990. Effect of ruminal microbial colonization on cereal grain digestion. Can. J. Anim. Sci. 70:571-579.

McCleary, B. V., V. Solah, and T. S. Gibson. 1994. Quantitative measurement of total starch in cereal flours and products. J. Cereal Sci. 20:51-58.

McDougall, E. I. 1948. The composition and output of sheep's saliva. Biochem. J. 43:99-109.

Miller, M. C., J. A. Froseth, C. L. Wyatt, and S. E. Ullrich. 1994. Effect of starch type, total $\beta$-glucans and acid detergent fiber levels on the energy content of barley (Hordeum vulgare L.) for poultry and swine. Can. J. Anim. Sci. 74:679-686.

Nara, S., and T. Komiya. 1983. Studies on the relationship between water-saturated state and crystallinity by the diffraction method for moistened potato starch. Starch 35:407-410.

Nolan, J. V., and R. A. Leng. 1974. Isotope techniques for studying the dynamics of nitrogen metabolism in ruminants. Proc. Nutr. Soc. 33:1-8.

NRC. 2001. Nutrient Requirements of Dairy Cattle. 7th rev. ed. Natl. Acad. Press, Washington, DC.

Offner, A., A. Bach, and D. Sauvant. 2003. Quantitative review of in situ starch degradation in the rumen. Anim. Feed Sci. Technol. 106:81-93.

Overton, T. R., M. R. Cameron, J. P. Elliott, J. H. Clark, and D. R. Nelson. 1995. Ruminal fermentation and passage of nutrients to the duodenum of lactating cows fed mixtures of corn and barley. J. Dairy Sci. 78:1981-1998.

Philippeau, C., J. Landry, and B. Michalet-Doreau. 1998. Influence of the biochemical and physical characteristics of the maize grain on ruminal starch degradation. J. Agric. Food Chem. 46:42874291

Plascencia, A., and R. A. Zinn. 1996. Influence of flake density on the feeding value of steam-processed corn in diets for lactating cows. J. Anim. Sci. 74:310-316.

Ramsey, P. B., G. W. Mathison, and L. A. Goonewardene. 2001. Relationships between ruminal dry matter and starch disappearance and apparent digestibility of barley grain. Anim. Feed Sci. Technol. 94:155-170.

Reynolds, W. K., C. W. Hunt, T. Moen, and J. A. Loesche. 1993. Comparison of corn and barley with and without ruminal buffer in supplements fed in wheat straw-based diets to beef steers. J. Anim. Sci. 71:1326-1334.

Rinne, M., P. Huhtanen, and S. Jaakkola. 2002. Digestive processes of dairy cows fed silages harvested at four stages of grass maturity. J. Anim. Sci. 80:1986-1998.

Rooney, L. W., and R. L. Pflugfelder. 1986. Factors affecting starch digestibility with special emphasis on sorghum and corn. J. Anim. Sci. 63:1607-1623.

Schroeder, J. W., G. D. Marx, and C. S. Park. 1998. Waxy corn as a replacement for dent corn for lactating dairy cows. Anim. Feed Sci. Technol. 72:111-120.

Soon, Y. K. 1998. Determination of cadmium, chromium, cobalt, lead, and nickel in plant tissues. Pages 193-198 in Handbook of Reference Methods for Plant Analysis, Y. P. Kalra, ed. CRC Press, Boca Raton, FL.

Svihus, B., A. K. Uhlen, and O. M. Harstad. 2005. Effect of starch granule structure, associated components and processing on nu- 
tritive value of cereal starch: A review. Anim. Feed Sci. Technol. 122:303-320.

Tang, H., K. Watanabe, and T. Mitsunaga. 2002. Structure and functionality of large, medium and small granule starches in normal and waxy barley endosperm. Carbohydr. Polym. 49:217-224.

Tothi, R., P. Lund, M. R. Weisbjerg, and T. Hvelplund. 2003. Effect of expander processing on fractional rate of maize and barley starch degradation in the rumen of dairy cows estimated using rumen evacuation and in situ techniques. Anim. Feed Sci. Technol. 104:71-94.

Udén, P., P. E. Colucci, and P. J. Van Soest. 1980. Investigation of chromium, cerium, and cobalt as markers in digesta. Rate of passage studies. J. Sci. Food Agric. 31:625-632.

Van Keulen, J., and B. A. Young. 1977. Evaluation of acid-insoluble ash as a natural marker in ruminant digestibility studies. J. Anim. Sci. 44:282-287.

Van Soest, P. J., J. B. Robertson, and B. A. Lewis. 1991. Methods for dietary fiber, neutral detergent fiber, and non-starch polysaccharides in relation to animal nutrition. J. Dairy Sci. 74:35833597.
Vasanthan, T., and R. S. Bhatty. 1996. Physicochemical properties of small- and large-granule starches of waxy, regular, and highamylose barleys. Cereal Chem. 73:199-207.

Yang, W. Z., K. A. Beauchemin, B. I. Farr, and L. M. Rode. 1997a. Comparison of barley, hull-less barley, and corn in the concentrate of dairy cows. J. Dairy Sci. 80:2885-2895.

Yang, W. Z., K. A. Beauchemin, K. M. Koenig, and L. M. Rode. 1997b. Comparison of hull-less barley, barley, or corn for lactating cows: Effect on extent of digestion and milk production. J. Dairy Sci. 80:2475-2486

Yang, W. Z., K. A. Beauchemin, and L. M. Rode. 2000. Effects of barley grain processing on extent of digestion and milk production of lactating cows. J. Dairy Sci. 83:554-568.

Yu, P. 2004. Application of advanced synchrotron radiation-based Fourier transform infrared (SR-FTIR) microspectroscopy to animal nutrition and feed science: A novel approach. Br. J. Nutr. 92:869-885.

Zinn, R. A. 1993. Influence of processing on the comparative feeding value of barley for feedlot cattle. J. Anim. Sci. 71:3-10.

Zinn, R. A., and F. N. Owens. 1986. A rapid procedure for purine measurement and its use for estimating net ruminal protein synthesis. Can. J. Anim. Sci. 66:157-166. 